\title{
The Development of Fitness Exercise and Muscle Hypertrophy Model for the Student Living in Boarding House
}

\author{
Rizki Muhammad Afif*, Djoko Pekik Irianto \\ Fakultas Ilmu Keolahragaan \\ Universitas Negeri Yogyakarta \\ Yogyakarta, Indonesia \\ *afifrizki@yahoo.com
}

\begin{abstract}
The purpose of this research was to produce a decent and effective exercise model to improve the fitness and muscle hypertrophy for the student who lives in boarding house. The research method used in this research was research and development method. This research was performed by adapting research and development steps from Sugiyono. The research methods were exercise models, which consist of fitness exercise model and muscle hypertrophy model. The exercise model was composed in a manual book. The exercise model had been validated by 3 experts and valid to be used to improve muscle mass up to 1,54. Meanwhile, the fitness exercise model could improve the body composition up to 0,61 , improve the muscle strength and durability up to 1,92 , improve the muscle flexibility up to 0,06 , and improve the lung and heart capacity up to 0,72 . Based on the research result, it concludes that: the exercise model which was developed had been tested for its feasibility and function to improve fitness and muscle hypertrophy of students who live in boarding house.
\end{abstract}

Keywords: fitness, exercise model, muscle hypertrophy

\section{INTRODUCTION}

In general, the definition of fitness (physical fitness) is the one's ability to do daily routines efficiently without getting overly exhausted/tired in order to have time to enjoy their relax time [1].

Stated, 5 components of physical fitness which related to health are below [2]:

- The lungs and hearts durability. The lungs and heart durability is the lungs and heart ability to supply oxygen for muscle to work for long time.

- The power of muscle. The power of muscle is the ability of a group of muscle to fight against the load of each movement.

- The muscle durability. The muscle durability is the muscle ability or group of muscles to work together to fight loads repeatedly.

- Flexibility and adjustability. Adjustability is the joints ability to move freely.
- Body composition. The body composition is the comparison between body and fat or body without fat which state by the percentage of body fat.

Obesity and over weight is the problem of public health which increase related to the chronic health condition [3]. Also the capacity of aerobic exercise which measured by the taking of maximum oxygen (VO2max) is the main cause of all disease of human's early death, not only normal disease but also cardiovascular disease [4,5]. Practice is the important component of the body weight management and the lungs and heart fitness. The clinic intervention study and the most update epidemiologic shows that the beneficial effect of the regular physical exercise could increase the intensity or the load of work in a day [6-8]. There are sufficient evident show that the ability to perform physical task determined by the level of muscle's power and durability limit. The individuals whom has lack of power/energy may not be able to perform their important daily activities. The functional degradation determined by at least part of muscle power/energy, flexibility and motion range, physical fitness and body composition, Patricia A.We found that cardiorespiratory fitness training, particularly involving walking, can improve exercise ability and walking after stroke. Mixed training improves walking ability and improves balance [9]

\section{METHOD}

The research was executed using the research method and development or often known as research and development. Research and development was a research method which was use to form new product and procedure, which then being tested, evaluated and screened systematically to meet the criteria, effectiveness, as well as the same specific quality and standard [10].

\section{A. The Development Procedure}

According to Sugiyono, there were steps in research and development which were: (1) to get to know the potential and the problem (2) data collection (3) product design (4) design validation (5) design revision (6) product test (7) product 
revision (8) trial test (9) product revision and (10) mass production [11].

1) Design trial: This product test was perform to collect data which will be use as the basic of the developed product feasibility. At this stage, the thing should be considered were (1) trial design (2) trial subject (3) the technical and instruments of data collection (4) data analysis technique

2) Trial subject: The trial subject in this research were the students in Yogyakarta whom live in 'Carehal' boarding house. The small scope trial involved 2 students, where as the bigger trial scope involved 10 students.

3) The data collection and technique: The instrument of this research is the evaluation form of the modest manual book of fitness exercise and muscle hypertrophy. Those instruments composed to find out the quality of the fitness exercise and the muscle hypertrophy. The evaluation performed by the content experts, media expert and language expert.

The data collected from this research were divided in two part which were qualitative data and quantitative data. The qualitative data was collected after (1) interview with the sports man (2) field record and (3) data of initial model draft suggestion and the observation result on the both small and big scope trial. The quantitative data was collected after (1) evaluation scale of draft moel validation score (2) evaluation scale of observation score of model execution, and (3) evaluation of trial questionnaire both big and small trial respondent.

\section{RESULTS}

\section{A. The Qualitative Data Result}

The researcher discovered that in reality there are many unproductive activities and more to spent time to relax, watch $\mathrm{TV}$, playing games and gathering around. Based on the search, observation and interview, actually boarding house members do not have many activities. They have monotonous activity in which affected the digression of their fitness. From 30 boarding house members, there were only 2 of them whom were concerns about their fitness, the rest did not really pay attention to the related matter.

After some observations and interviews, the researchers performed some fitness test towards 10 boarding house members and the muscle thickness measurement. Those fitness test were multistage test, leg and back dynamometer, push up, sit and reach, and fat calliper. The muscle hypertrophy test were using the measurement ribbon which was use at biceps, triceps, sub scapula and abdominal.

\section{B. The Quantitative Data Result}

The multistage test result showed that there were 2 persons with category 'sufficient' and 8 persons with category 'insufficient'. The leg and back dynamometer test result showed that there were 6 persons with category 'sufficient' and 4 persons with category 'insufficient'. The push up test result showed that there were 2 persons with category 'sufficient' and 8 persons with category 'insufficient'. The sit and reach test result showed that there were 4 persons with category 'excellent' and 3 persons with category 'sufficient' and 3 persons with category 'insufficient'. The sit and reach test result showed that there were 1 person with category 'excellent' and 2 persons with category 'sufficient' and 7 persons with category 'insufficient'. Where as, for the muscle thickness measurement, the result showed 10 persons gained 'insufficient' category.

The result of this research is a manual book of fitness exercise and muscle hypertrophy, which was readable and easy to execute for students who live in boarding house. Where as, the equipment aid which were use in this research was chair, bottle, backpack and stairs. The following was the model of fitness exercise and muscle hypertrophy which already transferred to a manual book:

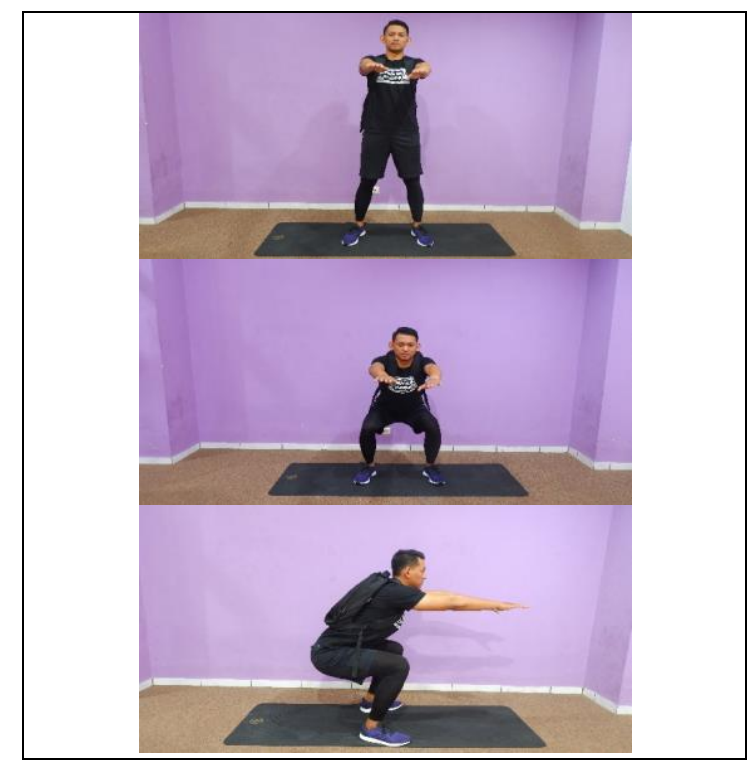

Fig. 1. Squat.

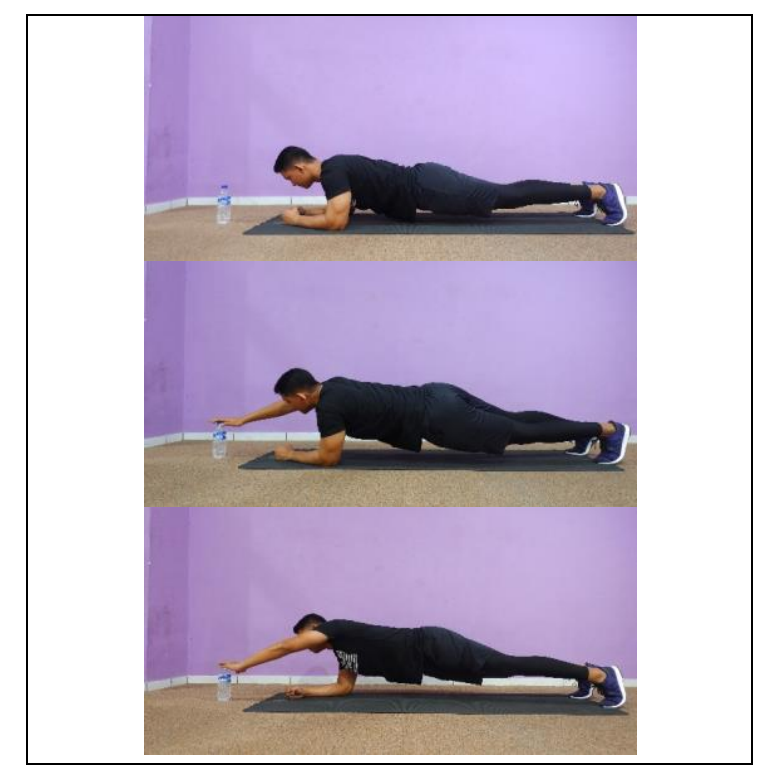

Fig. 2. Plank touch bottle. 


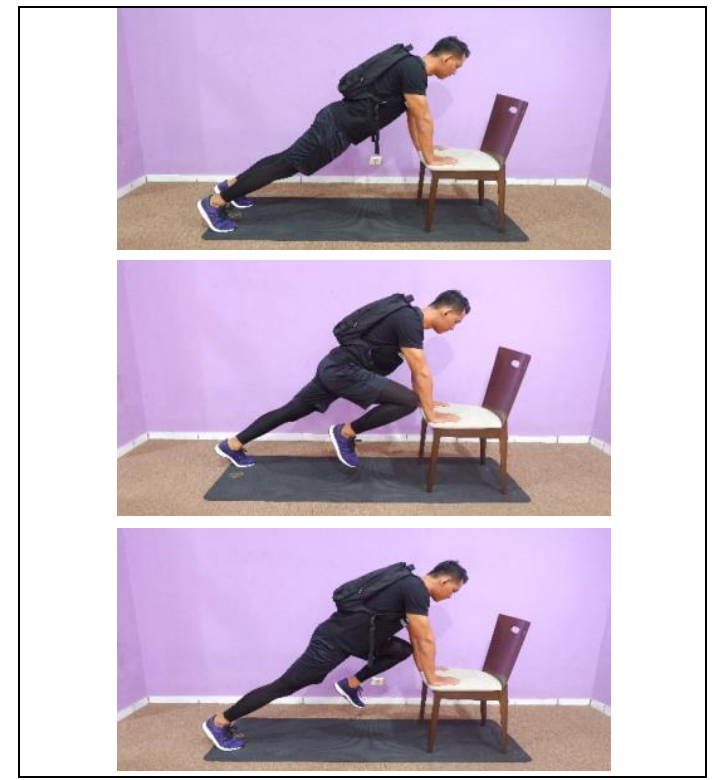

Fig. 3. Mountain climber using chair.

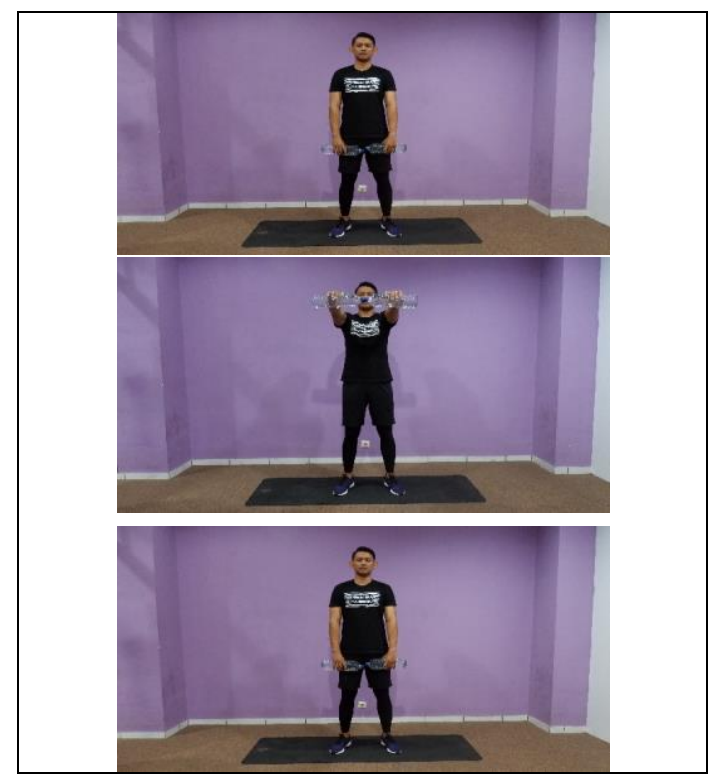

Fig. 4. Front rises using water bottle.

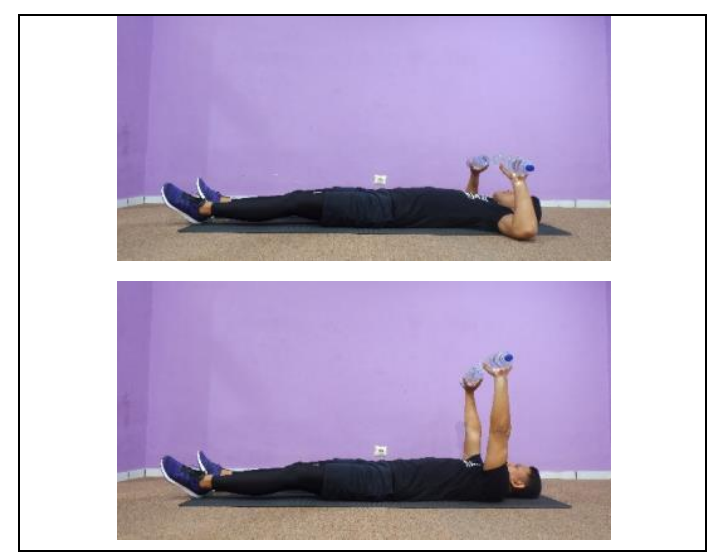

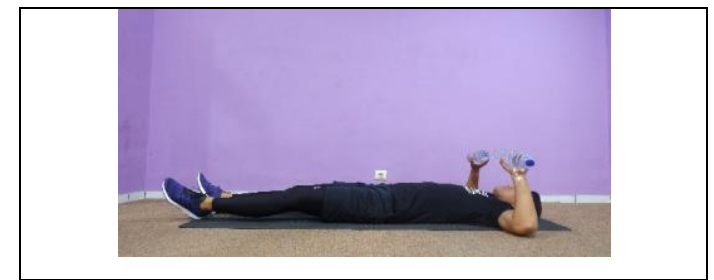

Fig. 5. Bench press using water bottle.

\section{DISCUSSION}

The low level of one person's fitness level was possibly determined by their daily physical activities. Different research also showed that the level of fitness activity potentially contributing good deal of fitness level, [12], therefore the daily physical activity was very important, as it will affect the physical fitness level. There were many factors that cause the low level of fitness level. The researcher discover a situation where a student who lives in a boarding house, some of them still did not put any concerns to their own body health, not in their lifestyle or their understanding of good and proper exercise.

From other research, it was stated that low level of physical activity becomes one of many factor that cause stroke [13]. Therefore, it was worrying if the potential disease been living since teenagers. Physical activity is very important for human body to prevent from disease and illness. Based on other researcher, when one perform physical activity along with flexibility exercise, it will decrease the joint and muscle pain as well as to perform better pose. The life of students in Yogyakarta is various, however most of their activities only spent by doing things which were nearly un-useful activity, which can be seen from the test result.

\section{CONCLUSIONS}

This research shows that the fitness activity model which performed in an indoor room with water bottle, backpack, chair and stairs demonstrate good and significant result to improve one's physical fitness. This can be seen from the improvement of lungs and heart durability, flexibility, strength and muscle durability as well as the decreasing amount of fat body. Apart from the fact, the muscle hypertrophy exercise model, which uses water bottle, backpack, chair and stairs, shows good and significant result. This can be seen from the improvement of muscle mass before and after routine exercise.

\section{REFERENCES}

[1] D.P. Irianto, "Bugar \& sehat dengan berolahraga," Yogyakarta: ANDI, 2004.

[2] Suharjana, "Kebugaran jasmani," Yogyakarta: Jogja Global Media, 2013.

[3] J.M. Jakicic, "Exercise in the treatment of obesity," Endocrinal. Metab. Clin. North Am, vol. 32(4), pp. 96780, 2003.

[4] M. Myers, V. Prakash, D. Froelicher, S. Do, Partington and E. Atwood, "Exercise capacity and mortality among men referred for exercise testing,” N. Engl. J. Med, vol. 346, pp. 793-801, 2002.

[5] D.K. Gulati, M.F. Pandey, D.S. Arnsdorf, R.A. Lauderdale, Thisted and R.H. Wicklund, "Exercise capacity and the risk of death in women," The 
[10] M.D. Gall, J.P. Gall and W.R. Borg, "Educational research: an introduction," 7th ed., New York: Pearson Education, Inc, 2003.

St James women take heart project, Circulation, vol. 108, pp.1554-1559, 2003.

[6] J.A. Gregg, K. Cauley, T.J. Stone, D.C. Thompson, Bauer and S.R. Cummingsm, "Relationship of changes in physical activity and mortality among older women," JAMA, vol. 289, pp. 2379-2386, 2003.

[7] H.D. Lee, Y. Sesso, Oguma and Jr. R.S. Paffenbarger, "Relative intensity of physical activity and risk of coronary heart disease," Circulation, vol. 107, pp. 1110-1116, 2003.

[8] E. Rognmo, Hetland, J. Helgerud, J. Hoff, and S.A. Slørdahl, "High intensity aerobic interval exercise is superior to moderate intensity exercise for increasing aerobic capacity in patients with coronary artery disease,” Eur. J. Cardiovasc. Prev. Rehabil., vol. 11, pp. 216-222, 2004.

[9] D.H. Saunders, M. Sanderson, S. Hayes, M. Kilrane, C.A. Greig, M. Brazzelli, G.E Mead, "Physical fitness training for stroke patients," Cochrane Database of Systematic Reviews, 2016.
[11] Sugiyono, "Metode Penelitian Kuantitatif, Kualitatif, dan R \& D," Bandung: CV Alfabeta, 2014.

[12] P. Gísladóttir, M. Haga, H. Sigmundsson, "Physical fitness measures among adolescents with high and low motor competence," Sage Open, vol. 3(3), 2013.

[13] J.A. Casey, B.S. Schwartz, W.F. Stewart and N.E. Adler, "Using electronic health records for population health research: a review of methods and applications," Annual review of public health, vol. 37, pp. 61-81, 2016. 